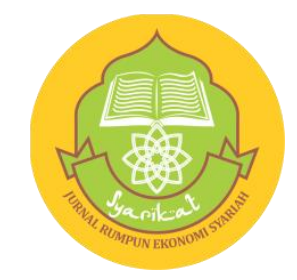

\title{
RELEVANSI UTILITY DAN MASHLAHAH DALAM MIKRO EKONOMI SYARIAH
}

\author{
Rahmawati', Husni Thamrin² \\ *1\&2 Prodi Ekonomi Syari'ah Program Pasca Sarjana UIN Sultan Syarif Kasim Riau \\ Email : 22190323212@students.uin-suska.ac.id
}

\begin{abstract}
Abstrak: Penelitian ini membahas relevansi utility dan mashlahah dalam ekonomi mikro syariah. Permasalahan yang sering terjadi yakni teori utility belum menyentuh prinsip dan tujuan yang paling mendasar dari konsumen Muslim, yaitu memenuhi kebutuhannya yang bersifat material dan non material, sulit membedakan antara keinginan dan kebutuhan, tidak dapat menghindari perilaku berlebihan. Sehingga belum dirasakan terpenuhinya kebutuhan ini dalam kegiatan konsumsi yang disebut mashlahah. Masalah-masalah tersebut harus ditemukan solusi dalam mengatasinya. Kehadiran ekonomi mikro syariah mampu memberikan titik terang dalam how dan why sebuah pengambilan keputusan setiap unit ekonomi yang di batasi oleh batasan-batasan syariah. Penelitian ini bersifat penelitian kepustakaan (library research) dengan metode tematik. Konsep utility atau kepuasan sangat berbeda dengan konsep maslahah atau kemanfaatan yag menjadi tujuan dalam konsumsi yang Islam. Konsep utility bersifat sangat subjek karena bertolak dari pemenuhan kebutuhan yang memang bersifat subjek. Sementara konsep maslahah relatif lebih obyektif karena bertolak dari pemenuhan keinginan yang memang relatif lebih obyektif dibandingkan kebutuhan. Karena konsep konsumsi dalam ekonomi mikro syariah adanya batasan-batasan dalam mengkonsumsi suatu barang/jasa yang sudah diatur dalam Al-Qur'an dan Hadist.
\end{abstract}

Kata Kunci : Utility, Mashlahah, Ekonomi Mikro Syariah

SYARIKAT : Jurnal Rumpun Ekonomi Syariah Volume 4, Nomor 2, Desember 2021 


\section{PENDAHULUAN}

Dalam ekonomi syariah, setiap tindakan ekonomi pada manusia akan didasari oleh prinsip-prinsip yang sesuai dengan ajaran Islam. Oleh karena itu setiap tindakan yang menyimpang dari syariat akan dilarang, karena bisa menyebabkan kemudharatan bagi umat manusia (Subagiyo, $2016: 3$ ).

Islam memposisikan kegiatan ekonomi sebagai salah satu aspek penting untuk mendapatkan kemuliaan (falah), dan karenanya kegiatan ekonomi sebagaimana kegiatan lainnya perlu dituntun dan dikontrol agar berjalan seirama dengan ajaran Islam secara keseluruhan. Pada kehidupan sehari-hari setiap individu ataupun kelompok suatu masyarakat tidak terlepas dari konsumsi, baik konsumsi suatu barang maupun jasa. Konsumsi pada hakikatnya mengeluarkan sesuatu dalam rangka memenuhi kebutuhan.

Dalam kerangka Islam perlu dibedakan dua tipe pengeluaran. Pengeluaran tipe pertama yaitu pengeluaran yang dilakukan seorang Muslim untuk memenuhi kebutuhan duniawinya dan keluarga (pengeluaran dilakukan untuk memenuhi kebutuhan dunia namun memiliki efek pada pahala di akhirat). Pengeluaran tipe kedua adalah pengeluaran yang dikeluarkan semata-mata bermotif mencari kebahagiaan di akhirat.

$\begin{array}{cccr}\text { Dalam } & \text { ekonomi mikro syariah } \\ \text { konsumsi } & \text { terhadap } & \text { barang di }\end{array}$
klasifikasikan dalam tiga kelompok, yaitu konsumsi barang primer (keperluan dasar), konsumsi barang sekunder (kenyamanan), dan konsumsi barang tersier (kemewahan). Sedangkan dalam bahasa ekonomi Islam tingkatan konsumsi terhadap barang-barang ini biasanya di istilahkan dengan barang- barang yang bersifat daruriyat, tahsiniyat, dan hajiyat (Ridwan et.al, 2017 : 79).

Pada dasarnya untuk mengkonsumsi suatu barang atau jasa, setiap individu umat Muslim dituntut dalam hal penggunaan tidak boros, tidak bermegah-megahan, dan lebih mengutamakan tujuan maslahahnya dari konsumsi itu sendiri. Hal ini berbeda dengan ekonomi konvensional, yang tidak memisahkan antara keinginan dan kebutuhan, sehingga terjebak dalam kategori konsumerisme. Karena tuntutan gaya hidup, banyak yang memprioritaskan keinginan mereka.

Sedangkan dalam perspektif ekonomi Islam tingkat kepuasan konsumsi seseorang harusnya berdasarkan kebutuhan dan mashlahahnya, bukan berdasarkan keinginan untuk mengkonsumsi suatu barang dengan kepuasan maksimum.

Teori ekonomi dibangun melalui pendekatan investigasi realistik terhadap fenomena-fenomena ekonomi. Investigasi ini difokuskan untuk mencari bagaimana pola perilaku hubungan antar variabel ekonomi. Dengan pendekatan model ini, teori ekonomi kemudian menjadi cukup ampuh untuk diletakkan sebagai alat analisis. Teori ekonomi dapat dengan sangat baik menjelaskan bagaimana kegiatan ekonomi berjalan dan dengan akurat memprediksi apa yang akan terjadi pada satu variabel ekonomi jika variabel yang mempengaruhinya berubah.

Teori utility menjelaskan bagaimana sikap rasional seorang konsumen dalam memenuhi kebutuhannya dan bagaimana seorang konsumen memaksimalkan utility yang diperoleh. Karena sifat dan keistimewaan inilah teori ekonomi kemudian justru memiliki kelemahan. Teori ekonomi dapat menjelaskan apa dan bagaimana seorang pelaku ekonomi 
membuat sebuah keputusan. Tetapi teori ekonomi tidak mampu menjelaskan keputusan mana yang paling maslahat ketika seorang pelaku ekonomi menghadapi berbagai alternatif yang akan dipilih.

Dikatakan mashlahat manakala keputusan yang diambil dapat memberikan manfaat tidak hanya yang bersifat material tetapi juga yang berhubungan dengan eksistensinya sebagai hamba yang akan mempertanggung jawabkan segala perbuatan kepada Allah Swt.

Berdasarkan latar belakang di atas, penulis tertarik menggali secara terperinci mengenai relevansi utility dan mashlahah dalam ekonomi mikro syariah.

\section{TINJAUAN PUSTAKA \\ Konsumsi}

Konsumsi secara umum adalah pemakaian dan penggunaan barangbarang dan jasa seperti pakaian, makanan, minuman, rumah, peralatan rumah tangga, kendaraan, alat-alat hiburan, media cetak dan elektronik, jasa konsultasi umum dll (Karim, 2004 : 260).

Konsumsi terhadap barang di klasifikasikan dalam tiga kelompok, yaitu konsumsi barang primer (keperluan dasar), konsumsi barang skunder (kenyamanan), dan konsumsi barang tersier (kemewahan). Kesenangan atau keindahan diperbolehkan asal tidak berlebihan, yaitu tidak melampaui batas yang yang dibutuhkan oleh tubuh dan tidak pula melampaui batas-batas makanan yang di halalkan. Dalam hal konsumsi Islam mengajarkan sangat moderat dan sederhana, tidak berlebihan, tidak boros, dan tidak kekurangan karena pemborosan adalah saudara setan.

Konsumen Muslim tidak akan melakukan permintaan terhadap barang sama banyak dengan pendapatannya, sehingga pendapatannya habis. Karena mereka memiliki kebutuhan jangka pendek (dunia) dan kebutuhan jangka panjang (akhirat) (Iifi, 2004 : 55).

Sedangkan dalam bahasan ekonomi Islam tingkatan konsumsi terhadap barang-barang ini biasanya di istilahkan dengan barang-barang yang bersifat daruriyat, tahsiniyat, dan hajiyat. Konsumsi barang daruriyat merujuk kepada barang-barang yang kelangkaannya akan menyebabkan seseorang mendapat kesulitan bahkan bisa menghilangkan keselamatan jiwa, agama, akal, keturunan dan harta. Konsumsi barang tahsiniyat adalah barang yang penggunaannya bukan untuk kenyaman melainkan untuk bermewahmewah. Konsumsi barang hajiyat adalah barang-barang yang ketersediaannya akan menyebabkan hidup seseorang menjadi lebih nyaman dan sempurna (Ridwan et.al, 2017 : 79).

Tujuan konsumsi konvensional yakni mengurangi nilai guna barang atau jasa secara bertahap. Setiap orang melakukan konsumsi akan mengurangi nilai guna barang atau jasa tersebut secara bertahap. Sebagai contohnya memakai pakaian dan kendaraan. Menghabiskan kebutuhan secara fisik seseorang melakukan konsumsi bertujuan untuk mencukupi kebutuhan mereka secara fisik. Sebagai contoh: mengenakan pakaian yang bagus agar penampilannya bertambah baik.

Sedangkan tujuan konsumsi dalam Islam konsumsi untuk diri sendiri dan keluarga. Allah Swt melarang perbuatan pemborosan dan berlebih-lebihan. Sebagai contoh: membeli makanan, pakaian dan lain-lain untuk dirinya dan keluarganya dirumah secara wajar. Konsumsi sebagai tanggung jawab sosial Islam melarang pemupukan harta, yang akan berakibat terhentinya arus 
peredaran harta. Contoh: Membayar Zakat, sedekah, dan infaq (Adesy, 2016:321).

Dalam kehidupan manusia yang paling mendominasi adalah sifat materialistis. Keinginan manusia adalah tidak terbatas, sehingga berbagai upaya manusia dilakukan cenderung hanya untuk dapat memenuhi dan memuaskan semua keinginan yang ada dalam diri mereka. Faktanya, manusia memiliki kelemahan dan kekurangan, sehingga tidak semua keinginannya dapat dipenuhi. Syariah Islam memiliki batasan dalam upaya untuk memenuhi keinginan dalam mengkonsumsi.

\section{Utility}

$\begin{array}{ccr}\text { Dalam } & \text { konsep } & \text { ekonomi } \\ \text { konvensional, } & \text { konsumen } & \text { dalam }\end{array}$ mengeluarkan uangnya diasumsikan selalu bertujuan untuk memperoleh kepuasan (utility) dalam kegiatan konsumsinya. Utility secara bahasa berarti berguna (usefulness), membantu (helpfulness) atau menguntungkan (advantage). Utility adalah suatu ukuran kepuasan/kebahagiaan yang diperoleh konsumen dari sekelompok barang (Ridwan et.al, 2017 : 21).

Dalam konteks ekonomi, utilitas dimaknai sebagai kegunaan barang yang dirasakan oleh seorang konsumen dalam mengonsumsi suatu barang. Karena rasa inilah maka sering kali utilitas dimaknai juga sebagai rasa puas dan kepuasan yang dirasakan oleh seorang konsumen dalam mengonsumsi suatu barang atau jasa. Jadi, kepuasan dan utilitas dianggap sama, meskipun sebenarnya kepuasan adalah akibat yang ditimbulkan oleh utilitas (Adesy, 2016 : 326).

Utility yang diperoleh tidak sematamata didasarkan pada fungsi barang yang dikonsumsi. Tetapi ada faktor lain yang melekat pada barang tersebut atau pada konsumen yang kemudian mempengaruhi keputusan konsumen tentang barang apa yang dianggap bisa memberikan utility paling tinggi. Ada beberapa faktor yang diidentifikasi dapat mempengaruhi tingkat utility yang diterima seorang konsumen, di antaranya adalah nilai guna barang tersebut, frekuensi konsumsi, tempat, selera, tingkat kebutuhan/keinginan konsumen, dan tingkat pengorbanan konsumen untuk mendapatkan barang tersebut (Rasul et.al, 2013 : 93).

\section{Mashlahah}

Mashlahah secara etimologi berarti sesuatu yang baik, dirasakan lezat, oleh karena menimbulkan kesenangan dan kepuasan serta diterima oleh akal yang sehat. Tujuan Allah Swt dalam menetapkan hukum adalah untuk memberikan kemaslahatan kepada umat manusia dalam kehidupannya di dunia maupun dalam persiapannya menghadapi kehidupan akhirat (Syarifuddin, 2008:232).

Sedangkan makna terminologinya yaitu: Al-Mashlahah adalah segala sesuatu yang bermanfaat bagi manusia, yang dapat diraih oleh manusia dengan cara memperolehnya maupun dengan cara menghindarinya. Seperti halnya menghindari perbudakan yang tentu membahayakan manusia (Fauzia, 2014:47).

Maslahah adalah segala bentuk keadaan baik material maupun non material, yang mampu meningkatkan kedudukan manusia yang paling mulia. Dalam konsep Islam kita akan mendapatkan kepuasan yang maksimum jika konsumsi kita mengandung mashlahah. Pencapaian maslahah merupakan tujuan dari syariat Islam (Maqashid Syariafi), yang tentu saja harus 
menjadi tujuan dari kegiatan konsumsi seorang Muslim (Adesy, 2016 : 326).

Menurut Jalal al-Din al-Rahman menyebutkan defenisi mashlahah yaitu:

$$
\text { الانسان نفع على الباعثة الأعمل }
$$

Artinya: "segala sesuatu yang mengandung manfaat bagi manusia".

\section{Jenis-jenis dan Sifat Mashlahah}

Pembagian maslahah secara umum dapat dibagi menjadi tiga bagian yaitu :

1. Al-mashlahah almu'tabarah adalah kemaslahatan yang bisa dijadikan hujjah dan tidak diragukan lagi penggunaannya. Dalam kasus hukum yang secara eksplisit dijelaskan dalam Al-Qur'an dan Hadis, kemaslahatan ini dapat ditelusuri melalui teks yang ada. Maka kemaslahatan seperti ini lazim dijadikan titik tolak penetapan hukum;

2. Al-mashiahahal nulghiih adalah kemaslahatan yang tidak ada teksnya dalam syari'ah, bahkan bertentangan dengan Al-Qur'an dan Hadis. Dan menjadikan mashlahah itu sendiri dihilangkan (mulghah) dan tidak dianggap. Kemaslahatan seperti ini dipandang batil oleh syara' dan tidak berlaku untuk menetapkan suatu hukum. Mashlahah ini bersifat sangat subjektif dan terkesan dibuat-buat.

3. Al-mashlahah al-mursalah adalah ketika tidak ada teks yang membatalkannya dan juga tidak ada ketentuaan khusus yang terkait dengannya. Atau bisa disimpulkan bahwa al-mashlahah almursalah dalah kemaslahatan yang tidak disebutkan ataupun dihapuskan oleh dalil syariah. Ketika ada suatu perkara, maka syari' (Allah) tidak mensyariatkan suatu hukum. Dan hakikat dari al-mashlahah almursalah dalah semua kemaslahatan dan juga manfaat yang masuk dalam area maqashid al-syari'ah, ketika hal tersebut tidak disyariatkan ataupun dihilangkan (Fauzia, 2014: 51).

\section{METODE PENELITIAN}

Penelitian pada metode ini menggunakan Penelitian Kepustakaan (Library Research). Dan yang di jadikan sebagai data primer dalam penelitian ini yakni data yang di peroleh langsung dari sumber utama yaitu buku-buku mengenai utility, maslahah dalam konsep ekonomi mikro syariah. Penelitian ini merupakan penelitian deskriptif yang mana akan mengkaji lebih jauh tentang relevansi utility dan mashlahah dalam ekonomi mikro syariah.

\section{PEMBAHASAN \\ Dasar Hukum Konsumsi}

Islam mengajarkan agar setiap manusia menyadari bahwa pemilik yang sebenarnya terhadap segala sesuatu yang di langit maupun di muka bumi, termasuk harta yang diperoleh oleh setiap manusia bahkan diri manusia itu sendiri adalah Allah Swt. Kepemilikan manusia terhadap harta bendanya hanya bersifat relatif, sebatas hak pakai. Hak pakai ini pun harus sesuai dengan peraturan-Nya. Kelak setiap manusia akan diminta pertanggungjawabannya tentang pemakaian harta benda yang dititipkan oleh Allah itu telah sesuai atau tidak dengan petunjuk dan ketentuan-Nya.

Semua harta benda telah diamanatkan Allah kepada manusia agar dijadikan sarana beribadah kepada-Nya. Di samping itu, selalu diingatkan Allah bahwa harta benda tidak hanya sebagai perhiasan hidup yang menyenangkan, tetapi juga sebagai pengujian keimanan dan ketakwaan seseorang keapadanya (Rivai, 2010: 17).

Konsep prilaku konsumsi dalam ekonomi Islam tidak boleh boros dan mengkonsumsi suatu barang/jasa secara 
berlebih-lebihan dan adanya batasanbatasan dalam konsumsi, karena konsumsi dalam ekonomi Islam harus memperhatikan tujuan dari ekonomi Islam itu sendiri yaitu mencari maslahah untuk mencapai falah, seperti yang terdapat dalam Al Qur'an pada Surah AlMaidah ayat: 87-88 :

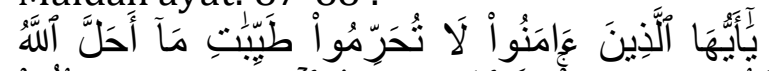

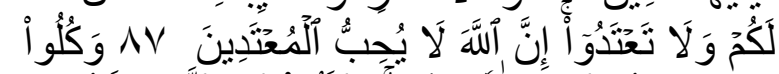

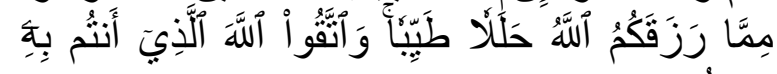

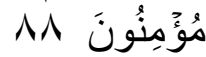

Artinya: "Hai orang-orang yang beriman, janganlah kamu haramkan apaapa yang baik yang telah Allah halalkan bagi kamu, dan janganlah kamu melampaui batas. Sesungguhnya Allah tidak menyukai orang-orang yang melampaui batas".

"Dan makanlah makanan yang halal lagi baik dari apa yang Allah telah rezekikan kepadamu, dan bertakwalah kepada Allah yang kamu beriman kepadaNya".

Dan juga dalam Surah Al-A'raf ayat 31 yang berbunyi:

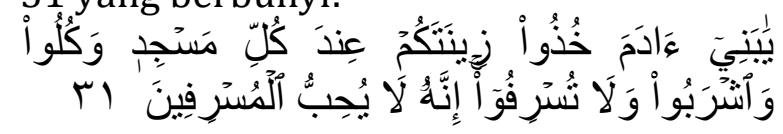

Artinya: "Hai anak Adam, pakailah pakaianmu yang indah di setiap (memasuki) mesjid, makan dan minumlah, dan janganlah berlebih-lebihan. Sesungguhnya Allah tidak menyukai orang-orang yang berlebih-lebihan".

Berdasarkan ayat Al-Qur'an dan di atas dapat dijelaskan bahwa yang dikonsumsi itu adalah barang atau jasa yang halal, bermanfaat, baik, dan tidak berlebih-lebihan (secukupnya). Tujuan mengkonsumsi dalam Islam adalah untuk memaksimalkan Maslahah (kebaikan) bukan memaksimalkan kepuasan (maximum utility).

\section{Analisis Relevansi Utility dan Mashlahah}

Konsumsi memiliki urgensi yang sangat besar dalam setiap perekonomian. Karena tiada kehidupan bagi manusia tanpa konsumsi. Oleh karena itu, kegiatan ekonomi mengarah kepada pemenuhan tuntutan konsumsi bagi manusia.

Dalam ekonomi mikro syariah, kepuasan konsumsi dikenal dengan maslahah dengan pengertian terpenuhi keputuhan baik bersifat fisik maupun spritual. Islam sangat mementingkan keseimbangan fisik dan dan non fisik yang didasarkan atas nilai-nilai syariah. Seorang Muslim untuk mencapai tingkat kepuasan harus mempertimbangkan beberapa hal, yaitu barang yang dikonsumsi adalah halal, baik secara zatnya maupun cara memperolehnya, tidak bersifat israf (royal) dan tabzir (siasia). Oleh karena itu, kepuasan seorang Muslim tidak didasarkan banyak sedikitnya barang yang dikonsumsi, tetapi didasarkan atas berapa besar nilai ibadah yang didapatkan dari yang dikonsumsinya (Rozalinda, 2014: 97).

Islam mengajarkan agar manusia menjalani kehidupannya secara benar, sebagaimana yang telah diatur oleh Allah swt. Ukuran baik dan buruk kehidupan sesungguhnya tidak diukur dari indikator lain melainkan dari sejauh mana seorang manusia berpegang teguh pada kebenaran. Selain itu juga harus mampu membedakan atara keinginan dan kebutuhan sebagaimana berikut :

Tabel 1. Perbedaan Keinginan dan Kebutuhan

\begin{tabular}{|c|c|c|}
\hline Karakteristik & Keinginan & Kebutuhan \\
\hline
\end{tabular}




\begin{tabular}{|l|l|l|}
\hline Sumber & Hawa Nafsu & Fitrah Manusia \\
\hline Hasil & Kepuasan & Manfaat dan Berkah \\
\hline Ukuran & Preferensi & Fungsi \\
\hline Sifat & Subjektif & Objektif \\
\hline Tuntutan Islam & Dibatasi/Dikendalikan & Dipenuhi \\
\hline
\end{tabular}

Perbedaan yang mendasar dapat kita lihat dari table di atas yakni kebutuhan merupakan hal yang tidak bisa di tunda, karena menjadi tuntutan bagi semua orang. Semua orang dapat merasakan fungsi, manfaat dan berkah (mashlahah) dari apa yang di konsumsinya. Sedangkan keinginan timbul dari hasrat manusia, dalam pilihan untuk mengkonsumsi sesuai dengan selera dan sifatnya subjektif, bisa berbeda antara seseorang dengan orang lain. Tetapi keinginan ini dapat dikendalikan, jika ditunda tidak akan mendatangkan kemudharatan. Jadi jelas Islam memisahkan antara kebutuhan dengan keinginan, karena jika mengikuti keinginan maka akan mengarah pada konsumerisme.

Teori nilai guna (utility) apabila dianalisis dari teori mashlahah, kepuasan bukan didasarkan atas banyaknya barang yang dikonsumsi tetapi didasarkan atas baik atau buruknya seseuatu itu terhadap diri dan lingkungannya. Jika mengonsumsi sesuatu tidak mendatangkan kemanfaatan pada diri atau lingkungan maka tindakan itu harus ditinggalkan sesuai dengan kaidah ushul fiqh :

$$
\text { المفافع جلب من أولى در عالمفاسد }
$$

Artinya: Menolak segala bentuk kemudaratan lebih diutamakan daripada menarik manfaat (Rozalinda, 2014: 99).

Jika mengkonsumsi sesuatu kemungkinan mengandung mudarat atau mashlahat maka menghindari kemudaratan harus lebih diutamakan karena akibat dari kemudaratan yang ditimbulkan mempunyai dampak yang lebih besar daripada mengambil sedikit manfaat. Jadi, perilaku konsumsi seorang Muslim harus senantiasa mengacu pada tujuan syariat, yaitu memelihara maslahat dan menghindari mudarat.

Dalam ekonomi konvensional, konsumsi diasumsikan selalu bertujuan untuk memperoleh kepuasan (utility). Konsumsi dalam Islam tidak hanya bertujuan mencari kepuasan fisik, tetapi lebih mempertimbangkan aspek mashlahah yang menjadi tujuan dari syariat islam.

Mashlahah dalam ekonomi mikro syariah, ditetapkan sesuai dengan prinsip rasionalitas Muslim, bahwa setiap pelaku ekonomi selalu ingin meningkatkan maslahah yang diperolehnya. Seorang konsumen Muslim mempunyai keyakinan bahwa, bahwasanya kehidupannya tidak hanya didunia tetapi akan ada kehidupan di akhirat kelak.

Perbedaan antara mashlahah dan utility yaitu:

1. Mashlahah individual akan relatif konsisten dengan mashlahah sosial, sebaliknya utilitas individu mungkin saja berseberangan dengan utilitas sosial. Hal ini terjadi karena dasar penentuannya yang relatif objektif, sehingga lebih mudah diperbandingkan, dianalisis dan disesuaikan antara satu orang dengan yang lainnya, antara individu dan sosial.

2. Jika mashlahah dijadikan tujuan bagi pelaku ekonomi (produsen, distributor dan konsumen), maka arah pembangunan menuju ke titik yang sama. Maka hal ini akan 
3. meningkatkan efektivitas tujuan pembangunan yaitu kesejahteraan hidup. Konsep ini berbeda dengan utilitas, dimana konsumen bertujuan memenuhi want-nya, adapun produsen dan distributor memenuhi kelangsungan dan keuntungan maksimal. Dengan demikian ada perbedaan arah dalam tujuan aktivitas ekonomi yang ingin dicapai.

4. Mashlahah merupakan konsep pemikiran yang terukur dan dapat diperbandingkan, sehingga lebih mudah dibuatkan prioritas dan pentahapan pemenuhannya. Hal ini akan mempermudah perencanaan alokasi anggaran dan pembangunan ekonomi secara keseluruhan. Sebaliknya akan tidak mudah mengukur tingkat utilitas dan membandingkan antara satu orang dengan yang lainnya, meskipun dalam mengonsumsi barang ekonomi yang sama dalam kualitas dan kuantitasnya (Fauzia, 2014:167).

Mengurangi konsumsi suatu barang sebelum mencapai kepuasan maksimal adalah prinsip konsumsi yang diajarkan Rasulullah, seperti makan sebelum lapar dan berhenti sebelum kenyang. Karena tambahan nilai guna yang akan diperoleh akan semakin menurun apabila seseorang terus mengonsumsinya. Pada akhirnya, tambahan nilai guna akan menjadi negatif apabila konsumsi terhadap barang tersebut terus ditambah. nilai guna marginal yang semakin menurun menjelaskan bahwa penambahan terus menerus dalam mengonsumsi suatu barang, tidak akan menambah kepuasan dalam konsumsi karena tingkat kepuasan terhadap barang tersebut akan semakin menurun.

\section{Kurva Indiferens (Kurva Kepuasan Sama)}

Kurva indiferens adalah kurva yang menunjukkan kombinasi beberapa barang yang ingin dikonsumsi oleh seseorang konsumen yang memberikan tingkat kepuasan yang sama. Ciri-ciri kurva indiferens :

1. Memiliki kemiringan/slope negative.

2. Cembung kearah titik origin (convex).

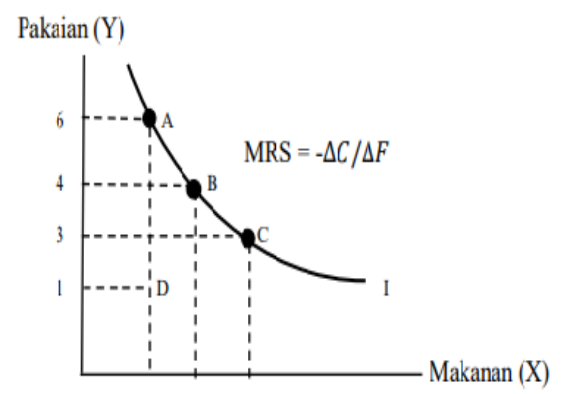

1. Semakin ke kanan menunjukkan tingkat kepuasan yang semakin tinggi.

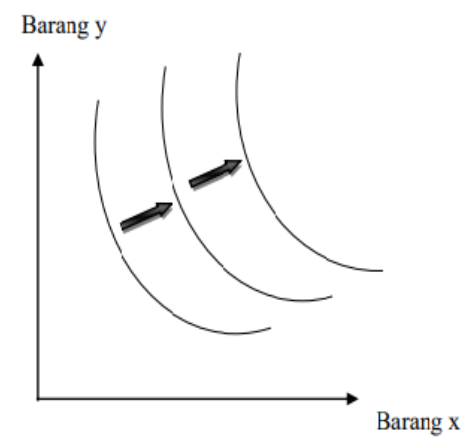

2. Tidak saling berpotongan.

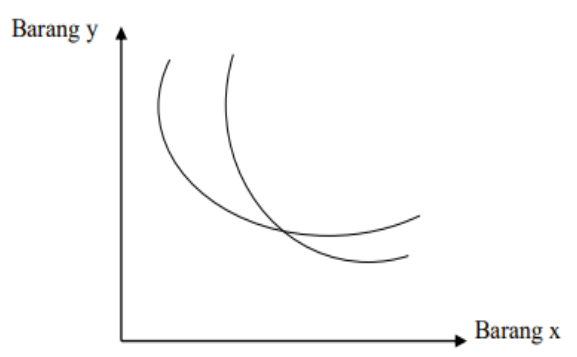

Dengan demikian maslahah adalah tujuan konsumsi untuk memperoleh kebahagiaan dunia dan akhirat. Maka dari itu tujuan konsumsi seorang Muslim 
bukanlah mencari utility, melainkan mencari maslahah. Konsep utility atau kepuasan sangat berbeda dengan konsep maslahah atau kemanfaatan yang menjadi tujuan dalam konsumsi yang Islam. Konsep utility bersifat sangat subjek karena bertolak dari pemenuhan kebutuhan yang memang bersifat subjek. Sementara itu konsep maslahah relatif lebih obyektif karena bertolak dari pemenuhan keinginan yang memang relatif lebih obyektif dibandingkan kebutuhan.

\section{SIMPULAN}

Berdasarkan uraian di atas dapat di tarik kesimpulan bahwa konsumsi memiliki urgensi yang sangat besar dalam setiap perekonomian. Karena tiada kehidupan bagi manusia tanpa konsumsi. Oleh karena itu, kegiatan ekonomi mengarah kepada pemenuhan tuntutan konsumsi bagi manusia. Dalam ekonomi mikro syariah tingkatan konsumsi terhadap barang-barang ini biasanya di istilahkan dengan barang-barang yang bersifat daruriyat, tahsiniyat,dan hajiyat. tujuan konsumsi dalam Islam Konsumsi untuk diri sendiri dan keluarga. Allah $S w t$ melarang perbuatan pemborosan dan berlebih-lebihan.

Konsumsi dalam ekonomi mikro syariah berbeda dengan teori konsumsi konvensioal dimana dalam konsumsi konvensional mengenal maximum utility. Hal in selalu diasumsikan bertujuan untuk memperoleh kepuasan (utility). Namun dalam teori Islam tujuan utama konsumsi ialah untuk memaksimalkan maslahah, bukan memaksimalkan kepuasan (maximum utility). Konsep utility bersifat sangat subjek karena bertolak dari pemenuhan kebutuhan yang memang bersifat subjek. Sementara itu konsep maslahah relatif lebih obyektif karena bertolak dari pemenuhan keinginan yang memang relatif lebih obyektif dibandingkan kebutuhan. Karna dalam konsep konsumsi dalam ekonomi mikro syariah adanya batasan-batasan dalam mengkonsumsi suatu barang/jasa yang sudah diatur sangat jelas dalam Al-Qur'an dan Hadist.

\section{DAFTAR RUJUKAN}

Adesy, Fordeby. (2016). Ekonomi dan Bisnis Islam. Jakarta: PT Raja Grafindo Persada.

Fauzia, Ika Yunia \& Abdul Kadir Riyadi. (2014). Prinsip Dasar Ekonomi Islam; Perspektif Maqashid alSyari'ah. Jakarta: Kencana.

Iifi, Diana. (2004). Hadits-Hadits Ekonomi. Malang : UIN Malang Press.

Karim. Adiwarman. (2004) Sejarah Pemikiran Ekonomi Islam. Jakarta: Raja Grafindo Persada.

Rasul, Abdul dkk. (2013). Ekonomi Mikro. Jakarta : Penerbit Mitra Wacana Media.

Ridwan, M et.al. (2017). Ekonomi Mikro Islam. Medan : Diktat.

Rivai, Veithzal \& Arviyan Arifin. (2010). Islamic Banking; Sebuah Teori, Konsep dan Aplikasi. Jakarta: Bumi Akasara.

Rozalinda. (2014). Ekonomi Islam; Teori dan Aplikasinya pada Aktivitas Ekonomi. Jakarta: PT. RajaGrafindo Persada.

Subagiyo, Rokhmat. (2016). Rancang Bangun Ekonomi Mikro Islam. Jakarta : Grafindo Persada.

Syarifuddin, Amir. (2008). Ushul Fiqih. Jakarta: Predana. 